\title{
HUBUNGAN KERJA PEMERINTAH DESA DENGAN LEMBAGA ADATDALAM PENGELOLAAN KEKAYAAN DESA DI DESA LUBUK SIAM KECAMATAN SIAK HULU KABUPATEN KAMPAR
}

\author{
Oleh: \\ Data Wardana ${ }^{1}$ \\ Yendri Nazir ${ }^{2}$ \\ Program Studi Ilmu Pemerintahan \\ Fakulas Ilmu Sosial dan Ilmu Politik \\ Universitas Islam Riau \\ Data.ip@soc.uir.ac.id
}

\begin{abstract}
Abstrak
Undang-Undang Dasar Negara Republik Indonesia Tahun 1945 membuka kemungkinan adanya susunan pemerintahan dalam system pemerintahan Indonesia. Maka keberadaan desa sangat penting dalam penyelenggaraan pemrintahan dan dalam rangka mewujudkan tujuan Nasional. Selain itu desa segai struktur pemerintaha yang terdepan sebagai ujung tombak keberhasilan pembangunan Nasional maupun pembangunan yang dilaksanakan oleh Desa Itu Sendiri. Salah satu Desa tersebut adalah Desa Lubuk Siam Kecamatan Siak Hulu Kabupaten Kampar. Dalam pelekasanaan pembangunan di Desa menggunakan dana desa dan pendapatan asli desa. Namun dalam pelaksanaannya pendapatanasli desa Lubuk Siam diterima oleh lembaga adat sehingga Pendapatan Asli Desa0 (nol) rupiah. Sementara desa mempunyai sumber pendapatan asli desa berasal dari sumbangan pihak ketiga, pengelolaan danau dan pendapatan lainnya yang sah. Penelitian ini bertujuan untuk Untuk mengetahui bagaimana hubungan kerja pemerintah desa dengan lembaga Adat Desa di Desa Lubuk Siam Kecamatan SiakHulu Kabupaten Kampar.Untuk mengetahui sistem pengelolaan Pendapatan asli desa (PAD) Desa Lubuk Siam Kecamatan Siak Hulu kabupaten Kampar. Metode yang digunakan dalam penelitian ini adalah kualitatif dengan tekni pengumpulan data adalah observasi, wawancara dan dokumentasi. Adapun yang menjadi informen penelitian adalah Kepala Desa, Lembaga Adat, Ketua BPD dan Tokoh Masyarakat serta Bendahara desa. Hasil penelitian adalah hubungan kerja Lembaga data dengan Pemerintah Desa dalam pengelolaan kekayaan desa adalah pertama: hubungan kemitraan dalam arti sama-sama mengelola pendapatan desa, hubungan koordinasi dengan musyawarah dan hubungan kontrol sosial dimana lembaga adat mengawasi penggunaan dana tersebut. Sedangkan sistem pengelolaannya di terima oleh lembaga adat dan dikelola oleh pemerintah desa untuk kegiatan pembangunan desa. Dari hasil penelitian dapat disimpulkan juga bahwa sistem pengelolaan pendapatan asli desa lubuk siam tidak sesuai dengan peraturan yang berlaku karena lembaga adat tidak diatur kewenangannya dalam pengelolaan kekayaan desa. Untuk perlu dilakukan pengawasan oleh pemerintah
\end{abstract}


dalam hal ini pemerintah Kabupaten Kampar. Agar pengelolaan tersebut tidak menyalahi aturan maka Desa Lubuk Siam Kecamatan Siak Hulu diusulkan menjadi desa adat.

Kata Kunci : Hubungan kerja, Lembaga Adat, pengelolaan kekayaan Desa.

\begin{abstract}
The 1945 Constitution of the State of the Republic of Indonesia opens the possibility of a government structure within the Indonesian system of government. Then the existence of the village is very important in the implementation of the government and in order to realize the National goal. Besides, the village is the leading structure of the government as the spearhead of the success of national development and development carried out by Desa Itu Sendiri. One of these villages is Lubuk Siam Village, Siak Hulu District, Kampar District. In the execution of development in the village using village funds and village income. However, in practice, the original income of Lubuk Siam village was accepted by the adat institution so that the original income of the village was 0 (zero) rupiah. While villages have original source of village income comes from third party donations, lake management and other legitimate income. This study aims to find out how the working relationship of village government with village customary institution in Lubuk Siam village Siak Hulu subdistrict of Kampar regency. To know the system of management of original income of village (PAD) of Lubuk Siam village of Siak Hulu district Kampar regency. The method used in this research is qualitative with the technique of data collection is observation, interview and documentation. As for the informant of the research are Village Head, Customary Institution, Chairman of BPD and Community Leaders and Village Treasurer. The result of the research is the working relationship of the Data Institution with the Village Government in the management of village wealthis first: the partnership relationship in the sense of equally managing the incomeof the village, the coordination relationship with the deliberation and the social control relationship in which the adat institution oversees the use of the fund. While the management system is received by customary institutions and managed by the village government for village development activities. From the result of the research, it can be concluded that the original village revenue management system of lubuk siam is not in accordance with the applicable regulations because the adat institution is not regulated by its authority in the management of village's wealth. To be supervised by the government in this case Kampar regency government. In order that the management does not violate the rules, the village of Lubuk Siam Subdistrict Siak Hulu proposed to be a traditional village.
\end{abstract}

Keywords: employment relationship, Customary Institution, Village wealth management. 


\section{Latar Belakang}

Keberadaan Desa diperkuat dengan Undang-Undang Dasar Negara Republik Indonesia Tahun 1945 Pasal 18 ayat (1) yang menyatakan " Negara Republik Indonesia di bagi atas daerah-daerah provinsi dan daerah provinsi dibagi atas kabupaten dan kota, yang tiap-tiap provinsi, kabupaten, dan kota itu mempunyai pemerintaha daerah, yang diatur denga undang-undang. Selanjut pada ayat (7) menegaskan, bahwa “ susunan dan tata cara penyelenggaraan pemintahan daerah diatur dalam Undang-Undang. Hal ini berarti bahwa Pasal 18 ayat (7) Undang-Undang Dasar Negara Republik Indonesia Tahun 1945 membuka kemungkinan adanya susunan pemerintahan dalam system pemerintahan Indonesia.

Gagasan untuk memajukan desa dengan cara yang rasionalisasi dan modernisasi dapat diketahui dari pemikiran Mohammad Yamin dan Soepomo yang disampakain dalam siding BPUPKI sebelum proklamasi kemerdekaan. Keduanya menggagas bahwa pemerinptahan di alam Indonesia merdeka akan disusun kedalam tiga tingkatan: 1) pemerintahan kaki yaitu desa; 2)pemerintahan tengah yaitu pemerintahan daerah; dan 3) pemerintahan atas sebagai pemerintah pusat. Gagasan ini mendukung maksud bahwa pemerintahan Indonesia merdeka mesti berpijak pada kaki yang kokoh, yaitu desa yang merupakan bentukan bangsa Indonesia Sendiri dengan susunan yang masih asli. Desa akan dirasionalkan dan dimoderenkan dengan menariknya kedalam system pemerointahan resmi, bukan tetap membiarkannya diluar seperti terjadi pada masa penjajahan. Karena mempunyai susunan yang asli, desa akan diberi status yang istimewa, sama halnya dengan daerah-daerah swapraja yang juga mempunyai susunan asli dan khas hasil pengembangan bangsa Indonesia sendiri.

Dalam penyelenggaraan pemerintahan Desa yang terdiri dari pendapatan asli Desa, bagi hasil pajak dan restribusi daerah Kabupaten/Kota, bagian dari dana perimbangan keuangan pusat dan daerah yang diterima oleh Kabupaten/Kota, alokasi anggaran dari Anggaran Pendapatan dan Belanja Negara, bantuan keuangan dari Anggaran Pendapatan dan Belanja Daerah Provinsi dan Anggaran Pendapatan Belanja Daerah Kabupaten/Kota, serta hibah serta sumbangan yang tidakmengikat dari pihak ketiga. Sumber pendapatan lain yang dapat disahkan oleh Desa bersal dari Badan Usaha Milik Desa, pengelolaan pasar Desa, pengelolaan kawasan wisata skala Desa, pengelolaan tambang mineral bukan logam, dan tambang batuan dengan tidak menggunakan alatberat, serta sumber lainnya yang tidak untuk dijualbelikan.

Dalam penyelenggaraan pemerintahan desa menggunakan sumber biaya baik dari APBN, APBD dan APBDes maupun sumber lainnya yang diatur dalam ketentuan peraturan perundang-undangan. Salah satu sumber dana berasal dari Pandapatn Asli Desa yang dimasukkan kedalam APBDes.

Fenomena yang terlihat di Desa Lubuk Siam Kecamatan Siak 
Hulu bahwa pendapatan Asli Desa dipungut dan dikelola oleh ninik mamak atau Lembaga Adat Desa. Sehingga pada tahun 2015 dalam APBDes Desa Lubuk Siam yang bersumber dari Pendapatan Asli Desa atau disingkat dengan PAD yaitu nihil atau 0 (nol) Rupiah. Sementara Di Desa Lubuk Siam banyak terdapat Perusahaan baik Perkebunan, Galian $\mathrm{C}$ dan perusahaan lainnya. Namun dalam pengelolaan PAD di kelola oleh Ninik Mamak, dana sumbangan pihak ketiga kepada Desa diterima oleh persatuan Ninik Mamak. Sejak berlakunya Undang-Undang Nomor5 Tahun 1974 tentang Pokok-Pokok Pemerintaha di Daerah, bahwa kekayaan desa dikelola oleh pemerintah. Namun lembaga adat desa Lubuk Siam tidak menyerahkan kekayaan desa tersebut karena masih menganggap bahwa itu adalah ulayat adat. Kemudian terdapat 12 (dua belas) Perusahaan yang terdapat di Desa Lubuk Siam Kecamatan Siak Hulu kabupaten Kampar. Namun dalam pengelolaan keuangan desa yang merupakan bantuan dari perusahaan tersebut dikelola oleh ninik mamak.

\section{Studi Kepustakaan konsep Negara}

Secara historis pengertian negara senantiasa berkembang sesuaidengan berkembangnya kondisi masyarakat pada saat itu. Pada zaman Yunani kuno para ahli filsafat negara merumuskan pengertiannegara secara beragam. Misalnya Aristoteles (384322 S.M)merumuskan negara dalam bukunya Politika, yang disebutnya sebagainegara polis, yang pada saat itu diartikan sebagai suatu wilayah yang kecil. Lanjut Aris Toteles Aristotels Negara adalah perpaduan beberapa keluarga mencakupi beberapa desa, hingga pada akhirnya dapat berdiri sendiri sepenuhnya, dengan tujuan kesenangan dan kehormatanbersama. Dalam pemahaman ini negara disebut negara disebut negara hukum, yang didalamnya terdapat sejumlah warga negara yang ikut dalam permusyawaratan yang kita kenal dengan istilah negara kota.

Sementara menurut konsep negara modern yang dikemukakan oleh Roger H. Soltau, negara adalah alat agency atau wewenang

lauthority yang mengatur atau mengendalikan persoalan-persoalan bersama atas nama masyarakat.Tokoh lain seperti Harold J. Lasky, juga mendefenisikan bahwa negara adalah suatu masyarakat yangdiintregasikan karena mempunyai wewenang yang bersifat memaksa dan yang secara sah lebih agung daripada individu atau kelompok, yang merupakan bagian dari masyarakat itu

Dengan demikian dapat dipahami bahwa negara meiliki wilayah dan wewenang atau kekuasaan yang mengikat warga negaranya. Melindungi hak-hak dasar warga negaranya untuk mencapai tujuan bersama. Hal ini juga senada dengan defenisi negara menurut Miriam Budiardjo dalam bukunya Dasar-Dasar Ilmu Politik bahwa negara adalah suatu organisasi dalam suatu wilayah yang memiliki kekuasaan tertinggi yang sah dan ditaati oleh rakyatnya. Setiap negara meiliki tujuan yang paling fundamental adalah melindungi hakhak dan mensejahterakan warga negaranya. Tujuan negara Republik 
Indonesia sebagaimana tercantum di dalam Undang-Undang Dasar 1945 ialah: " Untuk membentuk suatu pemerintahan Negara Indonesia yang melindungi segenap bangsa Indonesia dan seluruh tumpah dara Indonesia dan untuk memajukan kesejahteraan umum, mencerdaskan kehidupn bangsa, dan iikut melaksanakan ketertiban dunia yang berdasarkan kemerdekaan, perdamaian abadi, dan keadilansosial.

\section{Konsep Pemerintahan}

Menurut C.F Strong (1960) dalam Syafi'i pemerintahan dalam arti luas mempunyai kewenangan untuk memelihara kedamaian dan keamanan negara. Oleh karena itu, pertama harus mempunyai kekuatan militer atau kemampuan untuk mengandalikan angkatan perang, yang kedua harus mempunyai kekuatan legislatif atau dalam arti pembuatan undang-undang, yang ketiga harus mempunyai kekuatan finansial atau kemampuan untuk mencukupi keuangan masyarakat dalam rangka membiyai ongkos keberadaan negara dalam penyelenggaraan peraturan, hal tersebut dalam rangka penyelenggaraan kepentingan negara.

Pemerintahan menurut Ndraha adalah sebuah sistem multi proses yang bertujuan memenuhi dan melindungi kebutuhan dan tuntutan yang-diperintah akan jasa-publik dan layanan civil. Yang - diperintah lanjutnya adalahkomsumer produkproduk

pemerintahan, penanggung dampak1. negatif pembangunan, pembayar risiko mismanajemen negara, pemikul biaya sosial kegiatan para politisi, kambing hitam kegagalan para penguasa, korban upacara ritual kemenangan elite dalam mempertahankan kepentingannya, dan pembayar biaya penyelenggaraan negara serta gaji pemerintah

\section{Konsep Pemerintahan Daerah}

Sebagai pelaksanaan Pasal 18 UUD 1945 dibidang ketatanegaraan, pemerintah republik Indonesia melaksanakan pembagian daerahdaerah dengan bentuk susunan pemerintahannya diatur atau ditetapkan dengan Undang-Undang Pemerintahan Daerah. Dengan demikian penyelenggaraan pemerintahan daerah akanmengalami perubahan sesuai dengan perkembangan dan kemajuan daerah yang dituangkan dalam UndangUndang Pemerintahan daerah yang juga mengalami perubahan sejalan dengan kemajuan daerah untuk meningkat kesejahteraan masyarakat dalam rangka pemberian otonomi seluas-luasnya kepada daerah.

Ndraha menjelaskan masyarakat membutuhkan otonomi dalam rangka menyediakankebutuhan dan kelanjutan hidupnya, mengatur dan mengurus kepantingan-kepentingannya, sampai pada tingkat kualitas tertentu, sehingga daerah itu layak disebut daerah otonom Secara umum dapat dijelakan tentang asas penyelenggaraan pemerintahan daerah. Adapun asas tersebut adalah asas desentralisasi, asas dekonsentrasi, dan asas tugas pembantuan:

1. Desentralisasi.

Desentralisasi adalah penyerahan sebagian urusan dari 
pemerintah pusat kepada pemerintah daerah untuk mengurus danmengatur daerahnya sendiri.Mengatur sebagian urusan dimaksudtidak semua urusan dapat diserahkan pemerintah pusat kepada pemerintah daerah, seperti penyerahan urusan pertahanan dan keamanan akan menimbulkan keberanian daerah untuk melawan pemerintah pusat secara separatis.

2. Dekonsentrasi

Dekonsentrasi adalah pelimpahan wewenang dari aparat pemerintah pusat atau pejabat diatasnya (misalnya, wilayah provinsi). Menurut UU 32 Tahun 2004 Pasal 1 ayat (8); Dekonsentrasi adalah pelimpahan wewenang pemerintahan oleh pemerintah kepada Gubernur sebagai wakil pemerintah dan/atau kepada instansi vertikal diwilayah tertentu.

3. Tugas Pembantuan

Kata lain dari tugas pembantuan adalah Medebewind, Mede dalam bahasa Belanda artinya ikut serta atau turut serta, sedangkan bewind artinya berkuasa atau memerintah. Jadi pemerintah daerah ikut serta dalam mengurus suatu urusan tetapi kemudian urusan itu harus dipertanggunggjawabkan kepada pemerintah pusat. Tugas pembangtuan selalu berbarengan dengan asas otonomi.

\section{Konsep Otonomi Daerah}

Otonomi

adalah

"pemerintahan

sendiri"

(auto $=$ sendiri, nomes=pemerintahan).

Secara dogmatis, pemerintahan dipakai dalam arti yang luas. Berdasarkan ajaran catur-praja C.Van Vollenhoven, otonomi mencakup aktivitas, yaitu membentuk perundangan sendiri, melaksanakan pemerintahan sendiri, melakukan peradilan sendiri, melakukan tugas kepolisian sendiri.

\section{Konsep Pemerintahan Desa}

Keberadaan Desa baiksebagai lembaga pemerintahanmaupun sebagi entitas kesatuan masyarakat hukum adat menjadi sangat penting dan strategis. Sebgai lembaga pemerintahan, Desa merupakan ujung tombak pemberian layanan kepada masyarakat. Sedangkan sebagai entitas kesatuan masyarakat hukum, desa merupakan basis sistem kemasyarakatan bangsa Indonesia yang sangat kokoh sehingga dapat menjadi landasan yang kuat bagi pengembangan sistem politik, ekonomi, sosial-budaya, dan hukum yang stabil dan dinamais.

Desa menurut Nurcholis adalah suatu wilayah yang ditinggali oleh sejumlah orang yang saling mengenal, hidup bergotong royong, memiliki adat istiadat yang relatif sama dan mempunyai tata cara sendiri dalam mengatur kehidupan kemasyarakatannya. Sebagian besar mata pencahariannya adalah bertani atau nelayan. Pada desa daratan sebagian besar penduduknya mencari penghidupan sebgai petani baiksawah atau kebun, sedangkan pada masyarakat pesisir sebagian besar penduduknya mencari penghidupan sebagai nelayan.

\section{Konsep Hubungan Kerja}

Dalam hubungan kerja

dikenal dengan adanya komunikasi informasi dan komunikasi hubungan kerja. Komunkasi informasi biasanya disampaikan oleh pimpinan kepada unit-unit kerja dibawahnya melalui 
kegiatan apel kerja atau dalam suasana rapat, sedangkan komunikasi hubungan kerja adalah suatu cara dalam menyampaikan kegiatan yang harus dilaksanakan dengan tujuan agar kegiatan tersebut dapat berhasil, secara efektif dan efisien. Jika komunikasi diartikan sebagai proses interaksi dan penyampaian informasi, maka proses interaksi tersebut berlangsung dalam suatu jaringan kerja komunikasi yang dapat terjadi melalui struktur formal ataupun proses informal. Hubungan Pemerintah Desa dan Lembaga adat sebagai mitra dalam kerja dalam penyelenggaraan Pemrintahan Desa, pelaksaan pembangunan Desa, pembinaan kemasyarakatan Desa, dan Pemberdayaan masyarakat Desa. Hubungan kerja Lembaga kemasyarakatan Desa dengan Pemeintah Desa adalah hubungan kemitraan hal ini diatur dalam Undang-undang Nomor 6 tahun 2014 Tentang Desa pasal 94 yat 1-3 sebagai berikut;

1) Desa mendayagunakan lembaga kemasyarakatan Desa yang ada dalam membantu pelaksanaan fungsi penyelenggaraan Pemerintaha Desa, Pelaksanaan Pembangunan Desa, pembinaan kemasyarakatan Desa, dan pemberdayaan masyarakat Desa.

2) Lembaga kemasyarakatan Desa sebagaimana yang dimaksud pada ayat (1) merupakan wadah partisipasi masyarakat Desa sebagai mitra Pemerintah Desa.

3) Lembaga kemasyarakatan Desa bertugas melakukan pemberdayaan masyarakat Desa, ikut serta merencanakan dan melaksanakan pembangunan, serta meningkatkan pelayanan masyarakat.

Hubungan kerja lembaga data dengan pemrintah desa adalah hubungan kerja dalam bentuk kemitraan. Hubungan kemitraan diartikan sebgai hubungan kesetaraan. Menurut Pramono dalam Purwoko $(2204 ; 154)$ kemitraanberarti posisi pelaku sebagai "part" atau bagian, atau sebagai "partner"ambil bagian (mitra), yang dapat ditafsirkan sebagai:

a. Ada inisiatif untuk melakukan yindakan oleh "sang subyek"

$b$. Mempunyai kesetaraan atau kesederajatan posisi dalam melakukan tindakan bersamaorang lain (the other)

c. Masing-masing pihak bersediadan siap menanggung

konsekuensi bersama daritindakan yang sama-sama dilakukan tersebut;

d. Masing-masing pihak memepunyai "makna subyektif" yang sama (setidaknya mirip atau hampir) dalam menentukan dan melakukan tindakan bersama tersebut;

e. Tindakan yang sama-sama dipilih tersebut telah diproses dalam "ruang kesadara" secara sadar (dan mendalam) sehinggatindakan itu memang sesuatu yang dikehendaki untuk dilakukan.

\section{Metode Penelitian \\ Disain Penelitian}

Peneltian merupakan suatu hal yang amat penting dalam memecahkan suatu masalah. Penelitian memiliki metode untuk memudahkan dalam penyelesaian masalah. Menurt Ndraha metode dapat diartikan sebagai jalan (cara, 
pendekatan, alat) yang harus ditempuh (dipakai) guna memperoleh pengetahuan tentang suatu hal (sasaran kajian), baik yang lalu, kini, maupun yang akan datang: yang terjadi dan yang akan terjadi. Dalam penelitian ini penulis menggunakan metode penelitian deskriptif kualitatif guna untuk menjelaskan fenomena-fenomena yang terjadi dilapangan.

\section{Sumber Informasi}

Dalam penelitian ini penulis menggunakan sumber informasi, karena data yang diperoleh dari informan dan informan kunci. Maka sumber Informasi dalam penelitian ini adalah informan. Yang menjadi informan dalam penelitian ini adalah Kepala Desa Lubuk Siam, Anggota BPD dan Kepala Dusun, Lembaga Adat dan Tokoh masyarakat. Pemilihan informan diambil disetiap Desa yang diteliti, pemilihan Desa dilakukan secara Purposive. Selain informen penulis juga menggunakan Key Informance atau informen kunci untuk memperoleh informasi tentang penelitian. Key informance atau informan kunci dalam penelitian ini adalah informan yang dianggappaling mengetahui persoalan atau permasalahan dalam penelitian ini yaitu : Kepala Desa dan Ketua BPD dan Ketua Lembaga Adat

\section{Teknik Pengumpulan Data Wawancara.}

Teknik pengumpulan data dalam penelitian kualitatif lebih menekankan pada jenis teknik wawancara.

\section{Observasi}

Untuk mengetahui banyak tentang informasi lapangan peneliti melakukan pengamatan (observation) pengamatan dan atau observasi merupakan salah satu metode utama dalam pengumpulan data yang bisa dilakukan olehpeneliti. Observasi atau pengamatan merupakan metode pengumpulan data yang paling utama dalam penelitian kualitatif.

\section{Dokumentasi}

Dokumentasi merupakan suatu cara pengumpulan data yang menghasilkan catatan-catatan penting berhubungan dengan masalah yang diteliti, sehingga akan diperoleh data yang lengkap, sah dan bukan berdasarkan perkuiraan.

\section{Hasil Penelitian}

Desa memiliki sumber pendapatan Desa yang terdiri atas pendapatan asli Desa, bagi hasil pajak daerah dan restribusi daerah Kabupaten/Kota, bagian dari dana perimbangan daerah yang diteriima oleh Kabuoaten/Kota, alokasi dari Anggaran Penadapatan dan Belanja Negara, bantuan Anggaran Pendapatan dan Belanja Darah Provinsi, Anggaran Pendapatan dan Belanja Daerah Kabupaten/Kota, serta hibah dan sumbangan yang tidak mengikat dari pihak ketiga. Bantuan tersebut diserahkan kepada Desa dalam rangka percepatan pembangunan desa. Sumber pendapatan lain yang dapat diusahakan oleh Desa berasal dari Badan Usaha Milik Desa. Pengelolaan Pasar Desa, pengelolaan tambang mineral bukan logam dan tambang batuan dengan tidak menggunakan alat berat, serta 
sumber lainnya dan tidak untuk dijualbelikan.

\section{hubungan kerja pemerintah desa dengan lembaga Adat Desa di Desa Lubuk Siam Kecamatan Siak Hulu Kabupaten Kampar.}

Dari kutipan wawancara peneliti dengan informen maupunkey Informen diatas serta hasil observasi yang dilakaukan dapat diketahui bahwa bentuk hubungan Lembaga Adat Desa Lubuk Siam dengan Pemerintahan Desa dalam pengelolaan Pendapatan Asli Desa yang bersumber dari sumbangan pihak ketiga dapat dipaparkansebagai berikut:

\section{Hubungan Kemitraan}

\begin{tabular}{ccc}
\multicolumn{2}{c}{ Hubungan } & kemitraan \\
diartikan & sebgai & hubungan
\end{tabular}
kesetaraan. Berikut ini hasil wawancara peneliti dengan Kepala Desa Lubuk Siam Amri Jono Spd. Senin 21 November 2016 pukul 09.00 WIB.

Hubungan kita dengan lembaga adat adalah hubungan kemitraan dalam rangka membanguun desa agar masyarakat dapat diberdayakan. Selain itu kita selalu berkonsultasi dengan lembaga adat dan tokoh adat dalam penggunaan dana desa maupun kegiatan desa lainnya. Bahaka lembaga adat selalu dilibatkan dalam kegiatan desa. Kecuali dalam menerima pendapatan desa daripihak ketiga sampai hari ini belum bisa kita lakukan karena dari dulu yang meminta uangnya adalah lembaga adat. Kita tidak mau berkonflik dengan lembaga adat, apalagi posisi mereka sangat kuat karena masyarakat butuh lembaga adat.

Hala yang sama juga diterangkan oleh Ketua BPD Desa Lubuk Siam pada tanggal 29 November 2016 yang menerangkan bahwa:

Hubungan Pemerntah Desa dengan Lembaga Kemasyarakatan dalam penyelenggaraan pemerintahan desa adalah hubungan kemitraan. Artinya Pemerintah Desa bersama lembaga yang ada di desa sama-sama membangun Desa. Dalam penerimaan pendapatan Asli Desa sebenarnya adalah kewenangan desa, namun karena di Desa ini sejak dulu yang menerima dan mengelola lembaga adat karena memiliki kedudukan yang kuat dalam kehidupan masyarakat desa, maka hubungan kemitraan ini perlu dibangun dan dipelihara agar terjadi harmonisasi antara Pemerintah Desa dengan Lembaga Kemsyarakatan Desa terutama lembaga adat.

Dari wawancara diataas dapat diketahui bahwa hubungan kemitraan Pemerintah Desa dalam rangka pelaksanaan pembangunan desa. Lembaga kemasyrakatan desadengan Pemerintah desa sama-sama membangun desa. Berdasarkan hasil observasi peneliti dapat diketahui bahwa dalam pelaksanaan pembangunan di Desa dan pelaksanaan kegiatan-kegiatan dipemerintahan Desa selalu melibatkan lembaga adat. Pendapatan asli desa yang berasal dari sumbangan pihak ketiga diterima oleh lembaga adat, dan jika lembaga pemerintah desa membutuhkan dapat mengajukan kepada lembaga adat melalui rapat maupun surat resmi. 


\section{Hubungan koordinasi.}

Koordinasi suatu hak yang sangat penting dalam pelaksanaan kegiatan dalam rangka menyatukan persepsi dan tujuan agar tercapai sesuai dengan rencana atau kesepakatan yang telah ditentukan. . Berikut kutipan wancara penulis dengan kepala desa Lubuk SiamAmri Jono Spd Senin 21 November 2016 pukul 09.00 WIB.

Setiap penggunaan anggaran yang akan kita gunakan yang bersumber dari Dana Desa yang berasal dari sumbangan pihak ketiga selalu kita koordinasikan dengan lembaga adat, baik resmi melalui rapat desa, surat maupun secar tidak resmi misalkan mebicarakan secara persuasif dengan lembaga adat diluar forum resmi. Bahkan lembaga adat dilibatkan setelah itu baru kita ajukan surat permintaan dana kepada lembaga adat untuk keperluan kegiatan atau pembangunan yang akan kita lakukan.

Hal yang sama dinyatakan oleh Dt. Suku Melayu lembaga adat yang menyatakan bahwa:

Kita tentu mengeluarkan uang sesuai dengan kebutuhan desa berdasarkan hasil koordinasi kita dengan pemerintah desa. Kalau tanpa ada koordinasi mana berani kita mengeluarkan uang tersebut. Dengan demikian kita bisa mengawasinya sesuai atau tidak peruntukan dana tersebut.

Dari penjelasan hasil wawancara diatas dapat diketahui bahwa setiap penggunaan dana desa yang bersumber dari pendapatan asli desa dikoordinasikan antara pemerintah desa dengan lembaga adat. Koordinasi tersebut bisa dilakukan dengan pertemuan antara kepala desa dengan ketua Dt adat maupun melalui rapat yang dilaksanakan pleh pemerintah desa dengan lembaga adat serta dengan membuat surat resmi. Penggunaan dana tesebut dikeluarkan berdasarkan hasil koordinasi anata pemerintah dengan Dt adat. Inilah yang menjadi dasar bagi lembaga adat nantinya untuk mengeluarkan dana kas adat.

\section{Hubungan kontrol sosial}

Bentuk hubungan kerja Pemerintah Desa Lubuk Siamdengan Lembaga adat desa dalam pengelolaan dana desa yang bersumber dari sumbangan pihak ketiga adalah hubungan Kontrol Sosial atau pengendalian sosial. Berikut ini kutipan wancara penulis dengan informen berkaitan dengan hubungan kerja lembaga data dengan pemerintah desa dalam pengelolaan kekayaan desa dalam bentuk hubungan kemitraan. Hasil wawancara peneliti dengan ketua BPD Desa Lubuk Siam tanggal 29 November 2016 yang menerangkan bahwa:

Sebagai mitra pemerintah
dalam
pemerintahan desa dan memiliki
fungsi mengawasi pemerintah desa tentu setiap kegiatan pembagunan desa kita melakukan pengawasan. Dalam proses pengawasan sebenarnya masyarakat juga ikut mengawasi namun secara kelembagaan tentu BPD lah. Namun di desa lubuk siam lembaga adat juga ikut mengawasi yang juga memiliki kewenangan yang sama dengan kita dalam pengawasan jalannya pemerintahan desa terutama dalam kegiatan pembangunan apalagi 
dengan menggunakan dana desa yang diambil dari kas adat.

Dari pernyataan diatas dapat diekatahui bahwa Lembaga adat juga ikut mengawasi jalannya pemrintahan desa terutama dalam kegiatan pembangunan. Hal ini juga diaungkapkan oleh Kepala Desa Lubuk Siam Amri Jono Spd Senin 21 November 2016 pukul 09.00 WIB yang mengunkapkan bahwa:

Agar lembaga adat yakin dengan kegunaan uang yang kita minta untuk kegitan pembangunan, kita melibatkan Dt. Adat untuk mengawal proses pelaksanaan pembangunan yang bersumber dari dana desa yang dipegang oleh lembaga adat. Sehingga tidak ada lagi kecurigaan dan sesuai dengan hasil koordinasi kita dengan lembagaadat sehingga tidak disalah gunkan. Dan kita terima msemua masukan dan kritikan dari masyarakat terutama lembaga adat.

Pernyataan kepala desa diatas menerangkan bahwa lembaga adat difungsikanpemerintah desa untuk melakukan pengawasan kegitan pembangunan yang bersumber dari penndapatan desa. Keterangan ini dipertegas lagi dengan pernyataan Bendahara adat Desa Lubuk Siam Sihat (Dt. Majaindo) selas 13 desember 2016 pukul 16.30 WIB. Dana yang kita berikan kepada pemerintah desa atau kepala desa untuk kegiatan apapun apalagi pembangunan tentu kita harus tau kegiunaan uang itu, kita keluarkan sesuai dengan permitaan dan kita cek benar atau tidaknya untuk peruntukan uang tersebut. Kita awasi agar jangan salah diguunakan untuk hal-hal lain. Karena ini dana ulayat desa.
Dari hasil wawancara diatas dapat disimpulkan bahwa hubungan kerja lembaga adat dengan pemerintah desa dalam pengelolaan kekayaan desa yang bersumber dari pendapatan asli desa yang bersasal dari sumbangan pihak ketiga yang sifatnya tidak mengikat adalah hubungan kerja dalam melakukan kontrol sosial. Kontrol sosial dilakukan agar terjadi cek and balances dalam penyelengaraan pemerintahan desa anatara Pemerintah desa dan lembaga kemasyarakatan desa dalam hal ini lembaga adat.

Berdasarkan hasil observasi peneliti dapat diketahui bahwa lembaga adat ikut mengawasi semua kegiatan penggunaan anggaran yang dikeluatrkan oleh lembaga adat yang bersumber dari pendapatan asli desa. Lembaga adat meliki peran yang kuat dalam emlakukan pegawasan agar anggaran yang dikeluarkan tidak disalah gunakan dan sesuai dengan kesepakan awal yang sudah dikoordinasikan.

\section{Sistem pengelolaan Pendapatan asli desa (PAD) Desa Lubuk Siam Kecamatan Siak Hulu kabupaten Kampar.}

Proses penerimaan PendApatan Asli Desa dari sumbangan pihak ketiga. Berdasarkan hasil obsevasi peneliti dapat diketahui bahwa yangmenerima pendapatan asli desa adalah adalah lembaga adat. Lembaga adat yang menerima langsung dari pihak ketiga untuk selanjutnya di kas kan oleh lembaga adat. Dengan demikian dapat disimpulkan bahwa pendpatan asli desa dari sumbangan pihak ketiga 
diterima oleh lembaga adat atau nenek mamak.

1. Sistem pengelolaan pendatan asli Desa

Pendapatan Asli Desa Lubuik Siam di simpan dalam kas desa dan digunkan oleh pemerintah desa untuk keperluan kegiatan kemasyarakatan dan pembangunan desa. Seperti kegiatan kepemudaan, pembangunan tempat ibadah, pembelian tanah desa dan pembanguna desa lainnya. Kegunaan dana tersebut dikeluarkan oleh lembaga adat setelah melakukan koordinasi antara pemerintah desa dengan lembaga adat, baik resmi dengan musyawarah maupun pertemuan antara Kepala desa denga Dt. Adat dan bisa juga dengan meminta melalui surat resmi dari Pemrintah Desa kepada lembaga adat

\section{Kesimpulan}

Adapun kesimpulan dari penelitian ini adalah sebagai berikut:

1. Hubungan kerja dalam bentuk kemitraan yaitu pemerintah Desa dengan lembaga adat sama mengelola pendapatan aslli desa yang digunakan untuk kegitan pembangunan.

2. Hubungan dalam bentuk koordinasi, setiap kegunaan keungan yang berasal dari pendapatan asli desa tersebut dilakukan dengan koordinasi antara Pemerintah Desa dengan lembaga adat baik dalam forum formal dengan keputusan musyawarah maupun non formal dengan mengadakan pertemuan dan koordinasi antara Kepala Desa dengan Ketua Adat.

3. Hubungan kerja dalam bentuk kontrol sosial yaitu penggunaan dana desa tersebut oleh pemerintah desa dalam bidang pembangunan diawasi oleh lembaga adat, dan lembaga adat terlibat dalam kegiatan tersebut.

\subsection{Saran}

Adapun saran peneliti dalam penelitian ini adalah

1. Perlu dibuat mekanisme penggunaan dana desa yang yang bersumber dari pendapatan asli desa dari sumbangan pihak ketiga yang dituankan dalam Peraturan Desa jika ingin dikelola bersama dengan lembaga adat.

2. Perlu adanya persentase pembagian dana desa untuk pemerintah Desa dan untuk lembaga adat agar penggunaan dana tersebut bisa dipertanggung jawabkan dan lebih transparansi. Dengan ketentuan persentaseuntuk lembaga adat digunakan untuk kegitan adat dan untuk pemerintah desa dimasukkan dalam APBDEs atau kas Desa jikadikelola swecara terpisah.

3. Lembaga adat harus membuat laporan penggunaan dana karena dana tersebut adalah dana masyarakat desa atau Pendapatan Desa yang peruntukkannya untuk kegiatan pembangunan dan pemberdayaan masyarakat desa.

4. Diharapkan pemrintah Kabupaten kampar melalui Camat melakukan pengawasan dalam penggunaan dana Desa maupun pendapatan asli desa agar sesuai dengan peraturan yang berlaku.

5. Kepada pemerintah Kabupaten Kampar di usulkan agar Desa Lubuk Siam Kecamatan Siak Hulu kabupaten Kampar dijadikan sebagai Desa Adat. 


\section{Daftar Pustaka}

Ahmadi, Rulam. Metode Penelitian Kualitatif. Yogyakarta. ArRuzz Media.

Asshiddiqie, Jimly. 2012. Perkembangan \& Konsolidasi Lembaga Negara Pasca Reformasi. Jakarta; Sinar Grafika.

Awang, Azam. 2012. Pengembangan Organisasi Kajian Pemekaran Kecamatan, CV Indra Prahasta. Bandung.

Basrowi dan Suwandi, 2008. Memahami Penelitian Kualitatif, Jakarta. Rineka Cipta.

Bungin, Burhan 2012 Penelitian Kualitatif. Jakarta, Kencana Perdana Media Grup.

Haw Widjaja, 2009. Otonomi Daerah dan Daerah Otonom. Jakarta, Rajawali Pers.

Herliana Hasan,2014. Komunikasi Pemerintahan. Bandung, Rafika Aditama.

Kansil C.S.T. danChristin S.T. Kansil, 2008. Pemerintahan Daerah di Indonesia, Jakarta: Sinar Grafika Offset.

Ndraha, taliziduhu,2003. Kybernology (Ilmu Pemerintahan Baru), Jakarta, Rineka Cipta.

Ndraha, $\quad$ Taliziduhu. 2008. Kybernologi

Kepamongprajaan. Banten: Sirao Credentia Center.

Ndraha, 2010. Metodologi Ilmu Pemerintahan, Jakarta, Rineka Cipta.

Nurcholis,

Hanif.2011.

Pertumbuhan

dan pemerintahan desa.Erlangga. Jakarta

Satori, Djam'an dan Aan Komariah, 2010. Metodologi Penelitian Kualitatif, Alfabeta.Bandung.

Syafiie, Inu Kencana. 2011. Sistem Pemerintahan Indonesia. PT Rineka Cipta.Jakarta.

Syafiie, Inu Kencana.2013. Ilmu Pemerintahan. Jakarta, Bumi Aksara.

Syafi'i Inu kencana, 2013. Ilmu Pemerintahan Edisi Revisi, Jakarta, PT Bumi Aksara.

Syarifin, Pipin dan Dedeh Jubaedah.2010. Pemerintah Daerah di Indonesia, Pustaka Setia, Bandung

Sujarweni, Wiratna 2014. Metodologi Penelitian. Pustaka Baru Press. Yogyakarta

Wasistiono, Sadu dan Irwan Tahir, 2007. Prospek Pengembangan Desa.Bandung, Fokus Media.

di Keamatan, M. P. N. S., \& Hulu, S. Evaluasi Pelaksanaan Peraturan Pemerintah Nomor 45 Tahun 2007 Tentang Persyaratan dan Tata Cara Pengangkatan Sekretaris Desa.

Ispik, A., Yogia, M. A., Wedayanti, M. D., \& Zainal, Z. (2021). The Influence of Discipline on Performance of Employees Office of the Ministry of Religion. Pekanbaru City.

Subhayano, T., Yogia, M. A., Wedayanti, A. A. P. M. D., \& Zainal, M. L. H. (2021). Good Governance in Maintaining Peace and Order at Pangkalan Kerinci District. Pelalawan Regency.

Ispik, A., Yogia, M. A., Purwati, A. A., Wedayanti, M. D., \& Zainal, M. L. H. (2021). Analysis of 
Benefits, Discipline and Leadership Style in improving Employee Performance of the Ministry of Religion in Pekanbaru, Indonesia.

Nasri, H., Nurman, N., Azwirman, A., Zainal, Z., \& Riauan, I. (2022). Implementation of collaboration planning and budget performance information for special allocation fund in budget planning in the regional development planning agency of Rokan Hilir regency. International Journal of Health Sciences (IJHS) Ecuador, 6(S4), 639-651.

Munir, A., Wahyudi, S., \& Zainal, Z. (2020). Tinjauan Kriminologi Terhadap Sensual Marketing Sebagai Strategi Pemasaran Produk Yang Diperankan Oleh Sales Promotion Girl Di Kota Pekanbaru. Wedana: Jurnal Kajian Pemerintahan, Politik dan Birokrasi, 6(2), 21-35.

Subhayano, T., Yogia, M. A., Wedayanti, M. D., \& Zainal, Z. (2021). The Role of the Camat in Coordinating the Administration of Peace and Order in Pangkalan Kerinci District Pelalawan Regency.

Suwaryo, H. U., \& Redjo, H. S. I. (2018). Transformasi Hubungan Pemerintah Pusat Dan Pemerintah Daerah Dalam Pemberian Izin Hutan Tanaman Industri Bagi Swasta Di Provinsi Riau Tahun 2010-2015.

Wicaksono, A. (2022, April). Peatlands Restoration Policies in Indonesia: Success or Failure?. In IOP Conference Series: Earth and Environmental Science (Vol. 995, No. 1, p. 012068). IOP Publishing.
Yogia, A. S. M. A., Rahman, Z. M. D. W. K., \& Purwati, A. A. (2021). Leadership of Tourism and Culture Department in Development of Cultural Reserves at District Kuantan Singingi.

Zainal, Z., Rambey, R. R., \& Rahman, K. (2021). Governance of Household Waste Management in Pekanbaru City. MIMBAR: Jurnal Sosial dan Pembangunan, 37(2).

Halim, N. A., Rosidi, I., Haris, A., Yesicha, C., \& Riauan, M. A. I. Media dan Politik.

Riauan, M. A. I., Aziz, A., \& Nurman, N. (2020). Analisis Framing" Aksi Bela Islam" sebagai Dakwah Islam di Riau Pos (A Framing Analysis of" Islam Defense Action" as Islamic Dakwah on Riau Pos Newspaper). Jurnal Dakwah Risalah, 31(1), 35-47.

Riauan, M. A. I., Qurniawati, E. F., Aslinda, C., \& Aziz, A. (2020). Konstruksi Realitas Pada Pesan Politik Calon Walikota Pekanbaru di Riau Pos. ETTISAL: Journal of Communication, 5(1).

Riauan, M. A. I., Kholil, S., \& Sikumbang, A. T. (2019). Islamic Symbols on Political Messages in Newspapers in Riau (Study in Regional Head Election 2017). Budapest International Research and Critics Institute-Journal (BIRCI-Journal), 2(1), 254-262.

Riauan, M. A., Sari, G. G., Aslinda, C., \& Qurniawati, E. F. (2018). Konstruksi Makna Ketergantungan dalam Perilaku Merokok. Relasi Negara Industri Dan Masyarakat Dalam Perspektif 
Komunikasi, 171.

Riauan, M. A. I., \& Shasrini, T. (2017). Dampak Komunikasi Terapeutik terhadap Citra Pelayanan Kesehatan (Studi Kasus di Rumah Sakit Umum Daerah Arifin Achmad Pekanbaru). Jurnal The Messenger, 9(1), 31-43.

Riauan, M. A. I. (2016). Figur Politik Calon Walikota Pekanbaru Septina Primawati Rusli dan Erizal Muluk Pada Pemilukada Kota Pekanbaru 2011. Medium, 4(2).

Riauan, M. A. I. (2013). Penggunaan Teknologi Komunikasi dalam Penerapan Good Governance. Jurnal Kajian Pemerintahan, 2(2), 102-107.

Riauan, M. A. I. (2012). Studi Komparatif Aktivitas Humas Antara Pemerintah Provinsi Riau dengan PT. Chevron Pacific Iindonesia. Medium, 1(1).

Sari, G. G., Wirman, W., \& Riauan, M. A. (2018). Pergeseran Makna Tradisi Bakar Tongkang Bagi Generasi Muda Tionghua di Kabupaten Rokan Hilir Provinsi Riau. 